\title{
12.
}

612.015 .32

\section{酸及ビ「アルカリ」性緩衝液注入ノ含水炭素 新陳代謝ニ及ボス影響二就テノ實騟的研究}

（第 2 報）

酸及ビ「アルカリ」性緩衝液ト「アドレナリン」 站ニ「インシュリン」合併注射, 家鬼血糖量 及ビ體溫二及ボス影響二就テ

用山贯科大悬柿沼內科敌室

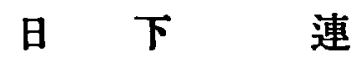

[昭和 8 年 5 月 20 日受棃]

Aus der Med. Klinik von Prof. Dr. K. Kakinuma, der Med. Fukultät Okayama.

Experimetelle Studien über die Beeinflussung des Kohlehydratumsatzes durch Injektion saurer und alkalischer Puffergemische.

\section{Mitteilung.}

Über die Beeinflussung des Blutzuckers und der Körpertemperatur beim Kaninchen durch Injektion saurer und alkalischer Puffergemische mit Adrenaliu oder Insulin.

$$
\text { Yon }
$$

Ur. Muraji Kusaka

Eingegungen am 20. Mai 1933.

Verfasser untersuchte die Beeinflussung des Blutzuckers und der Korpertemperatur beim Kaninchen durch Injektion saurer und alkalischer Puffergenische mit Adrenalin oder Insulin.

Auf Grund seiner Untersuchungen kam er zu folgenden Schlüssen : 
1) Durch die kombinierten Injektionen von alkalischem isotonischen Puffergemisch ( $\mathrm{Ph}$ 8.2) und Adrenalin wird eine starke Hemmung der Adrenalinhyperglykämie und eine mässige Korpertemperntursteigerung erzielt.

2) Die Injektion von saurem Phosphatgemisch ( $\mathrm{Ph} \mathrm{6.2)}$ und Adrenalin bewirkt eine Verstärkung der Adrenalinhyperglykämie und eine leichte Steigerung der Korpertemperatur.

3) Durch zufuhr von Insulin mit alkalischem Phosphatgenisch ( $\mathrm{Ph} \mathrm{8.2)} \mathrm{wird} \mathrm{eine}$ erhebliche Fiebertemperatur erhalten, aber keine merkliche Beeinflussung der Blutreduktionswerte hervorgerufen.

4) Wenn man Insulin und saures Phosphatgemisch gleichzeitig injiziert, so gelingt zwar eine mässige Körpertemperatursteigerung, aber keine Veränderung der Bluteduktionswerte. (Autoreferat).

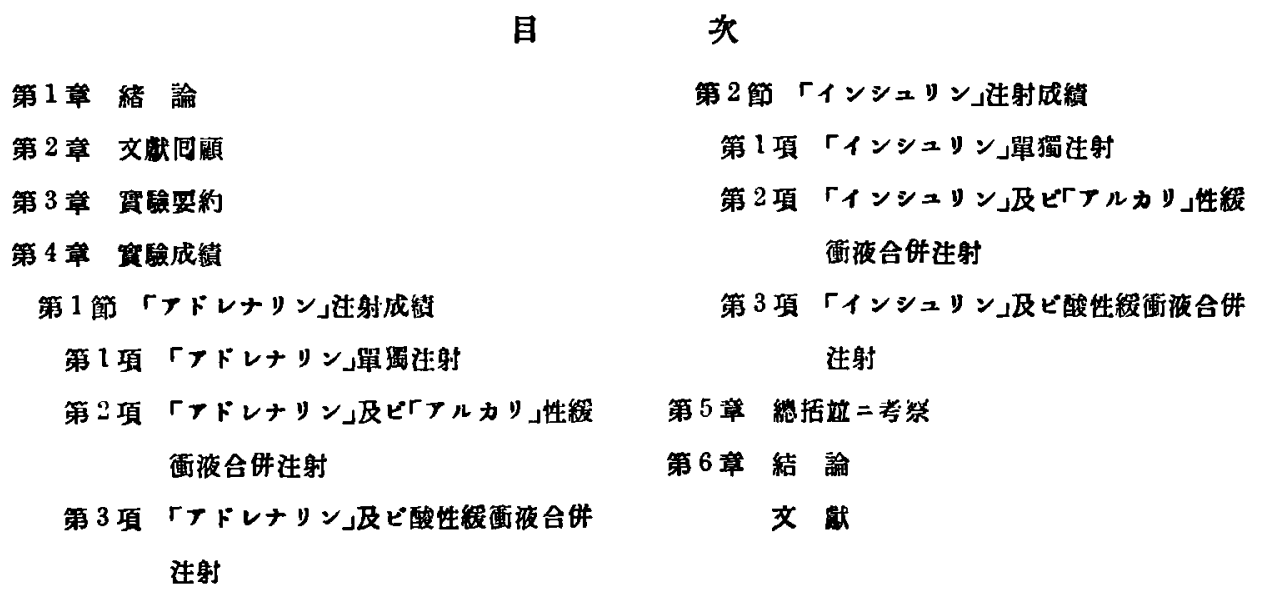

\section{第 1 垂緒論}

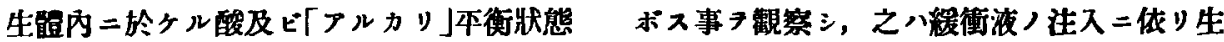
ガ諸種生物學的反應ト密接ナル關保フ有スル 事八各方面ヨリ觀察サルル所ニシテ，物筫代 體二擱フ來シー過性二榶ノ燃燒坦加シタル モノナラントノ推論タ下セリ。更二余八之等 謝殊二含水炭素ノソレトノ干慗モ幾多究明七 䌐遇液ト「フドレナリン或ハ「インシュリン」

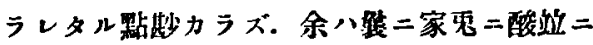

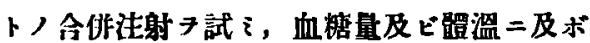

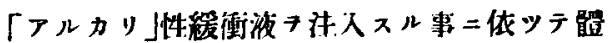
ス影謷子觀繁シタルキ以テ，以下順次記述シ

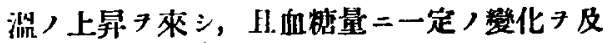
俳七テ諸家ノ比判フ仰ガント欲ス。 


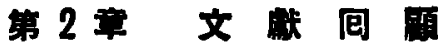

「マドレナリン」，作用八肝矌，Glykogenolyse

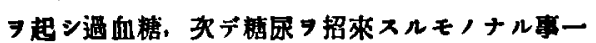
般二詔メラレタル虎ナリ、Cori1)氏及 Mornezew ski u. Lindner2) 氏等ハ「ナドレナリン」注射後尿中二

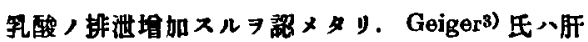
除去犬及ビ蛙 7 用七，又犬，蛙／四肢，瀖流 7 行

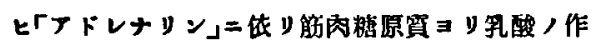

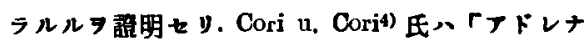

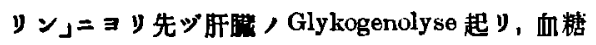

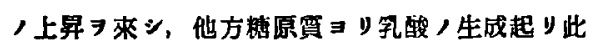
= Lactucidimie $\Rightarrow$ 來シ，更二等酸八肝中ニテ榶

Leberglykogenolyse $\rightarrow$ Hyperglykiimia $\rightarrow$ Glykogeuie in den Muskeln $\uparrow \quad$ (Glykosurie)

Leberglykogenie $\leftarrow$ Hyperlactncidkmie $\leftarrow$ Glykolyse in den Muskeln (Lactacidurie)

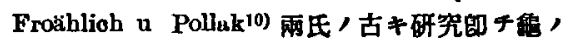

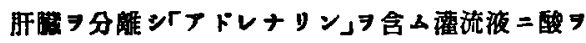
加フレハ:Zuckermobilisution 增强サレ「ナルカリ」 フ加フレバ低下シ，時二メ全ク抑制サルル結果ヨ 得明.

Gottschulk u. Pohle"11氏ハ「ナドレナリン」注射

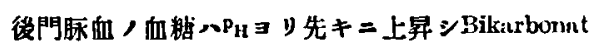
浴液 $\Rightarrow$ 經口的二與フレパフドレナリン」過血极， 强キ抑制建ルコトラ要見セリ。

nderhjl12) 氏八正常家电 = Trinatriumphosphat

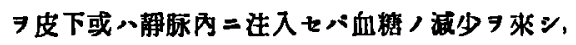
更ニ「アドレナリン」過血糖/減少７見几、コハ Trinatriumphosphat, Calciumentziehnng，作用 $=\Xi ル+y \vdash$.

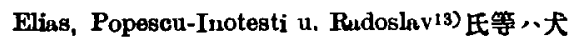
及ビ家鬼二於テ第 1 站二第 2 燐酸盖，注入八厂

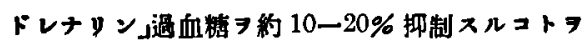
立證セリ．Fujimakj(1)，Bricker(6)，西元这衛(6) 氏 零モ同樣，結果二到崖セリ.

Colluzo, Faindel u. Rabino17), Allın, Dieckson
原買二再生サルナりト云ーリ，Sahyun n. Luok5)

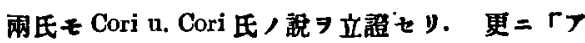
ドレナリン」注射ニヨリ過血糖ト同時二血中学醙 量,增加 7 來スコトハ多ク，學者ノ一敄七几結果 + y (Cori1), Cori und Cori4), Subyun u. Luek5), Junkersdorf $u$. Toeroek ${ }^{6}$ ), Geiger $\mathfrak{u}$. Sohmidt?), 中家茂狄 ${ }^{8>}$, Colluzo u. Puyal9)).

Collazo u. Puyul9) 氏八含水宸素, Anoxydativer Umsntz 二對スn「アドレナリン」ノ作用 7 头，如 ク略記セり。

u. Markowitz18), Eadie, Maoleod u. Nobel19), Kurokawa 20), Bollinger u. Bartmann21), Oda22), 諸氏ハ「アドレナソン」往射ニョリ血中及ビ尿中二

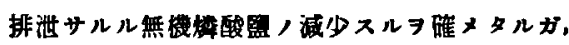
Moruezewski n. Lindner ${ }^{23)}$ ，Faeta24) 氏等八反璟 ニ「テドレナリン」注射ニヨリ尿中無機燐酸，增加

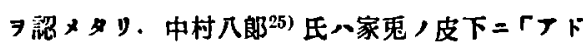
レナリン」每 kg 0.5-1.0 c $(1: 1000)$ ，注射二ヨ

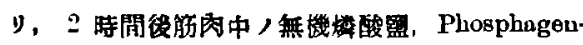
phosphut 八減少シ，繶溜酸性燐，Luctucidogenphosphat 八增加\%，無機燐酸監八最初(45 分後) 著明ナル $(36 \%) ， 2$ 時間後二八亥度 $(6.6 \%)$ ナル 垭加 7 示セり.

寺田 ${ }^{26)}$ 氏八家鬼ニ「ナドレナリン」0.15c，静豚

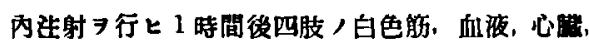

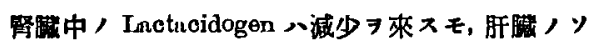

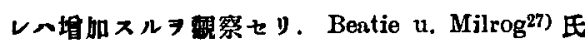

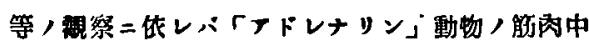

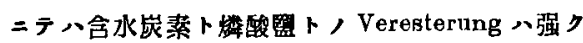

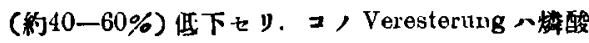




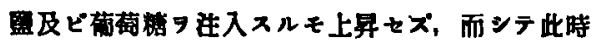

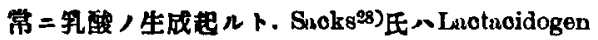
ノ分解二及ボス「マドレナツン」ノ作用ヨ楥シ「ナ

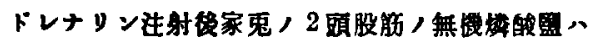
㘿加スル

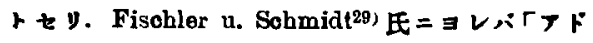
レナリン」或ハ「ェフェドロール」=ヨル Innere

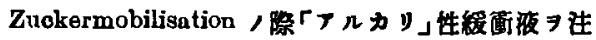

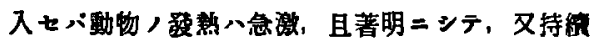
時間長シト. 西元 ${ }^{16)}$ 氏ハ「ドレナリン」, Thyrop-

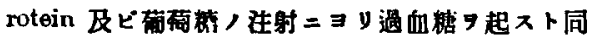

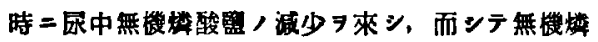

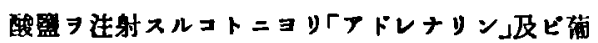

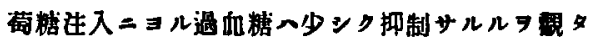
y.

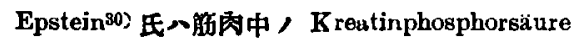

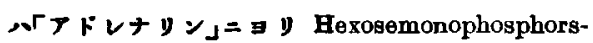

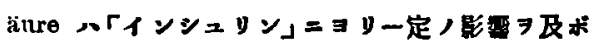

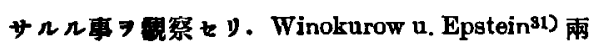

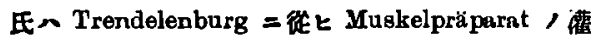

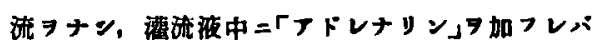

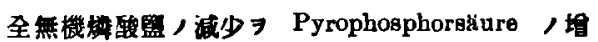

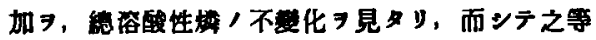

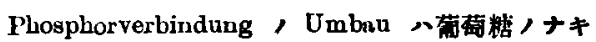
時ハ起ラズト.Feinschmid a. Ferdmann32) 兩氏

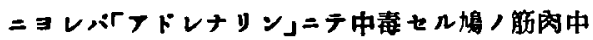
ニテハー方 Phosphagen 一分解サレ，等酸，生成， $\exists$ 來シ，他方 Lactacidogen 八增加七りト. Oda22

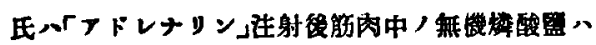
減少シ, Phosphagen，增加 7 来セル

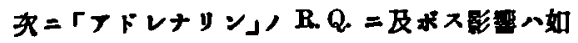
何ト云フニ，一般二「ナドレナリン」住射二ョり

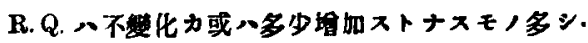
(T. Tsuohtschenko ${ }^{33)}$, Gradinesou ${ }^{34)}$, Ascher ${ }^{86)}$, Gintenberg ${ }^{36)}$ ).

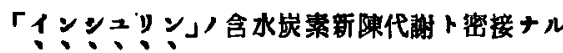

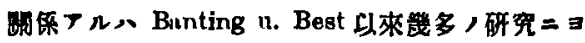

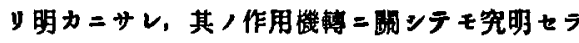

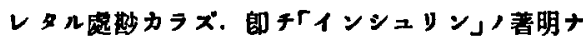

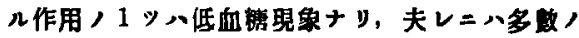
原因ナレドモ盟スルニ粕ヨリ，糖原生成及ビ硬， Oxydative Spultung ガ主因ナ リ. Burn u. Dules7) 雨氏 dekapitierte $u$. eviscerierte Kntze $\Rightarrow$ 用

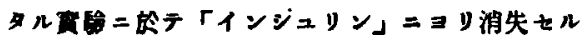

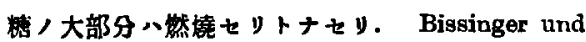

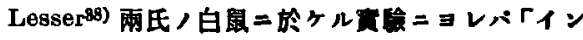
ンニリン」ニヨリ消失七几糖，大部分心然燥セル モ，小部分カ糖原二合成セラルルモノニシテ其

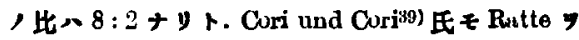

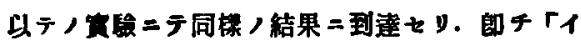

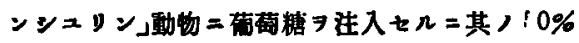
八酸化七ラレ, $38 \%$ 八筋肉中二, $4 \%$ 八䀒睡中=

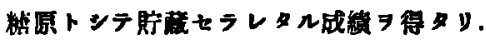

Kawamura(0), Neuberg, Gottschnlk u. Strauss41) 氏等ハレインシュリン」ニヨy個鳁中二Acetaldehyd

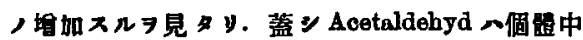
=於テ圭二含水炭素，酸化分解=ヨリ生ズルモ，

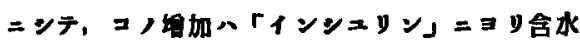
炭素ノ然嬈促進习意味スルモノナリ (Neuberg $\mathbf{n}$. Gottschalk42;).

更二肝糖原貫二及ボス「インシンリン」ノ作用

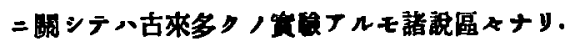

Dudley u. Marrian43), Brugsoh45), Gigon u. staub46), Macleod47), Nitzesou u. Popesou-Ino-

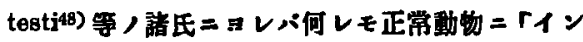

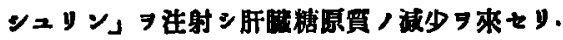
侗水 Macleod 49)氏，Brugsoh 4)氏零心「インシニ ソン」ト同時二荷萄糖

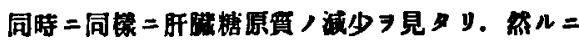
Bissinger ${ }^{50)}$, Lesser ${ }^{51}$ ), Bindi52), Rubino, Varela u 
Colluz063)，諸氏ハ「インンニリン」ト同時二蒲荡

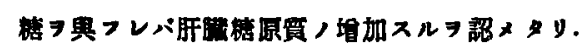

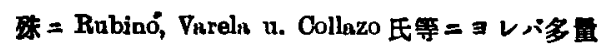
ノ含水炭菜卜同時ニ「インンニリン」ヨ注射スレハ

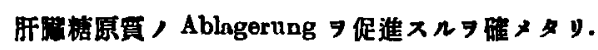

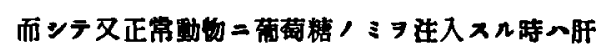

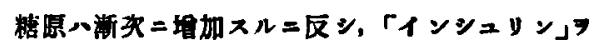
同時二连射ス几時八肝糖原八速二㘿加シ，又直二

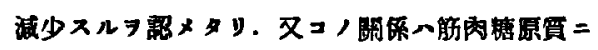

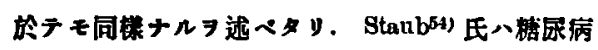

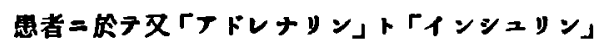

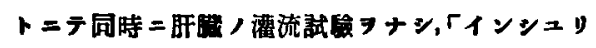

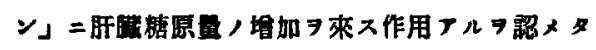
y.

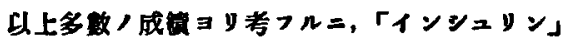

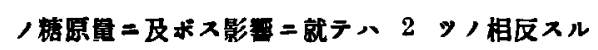

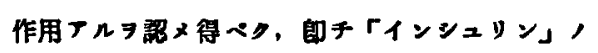
第一夲作用トシテハー方糖原，生成 $\exists$ 促進ン，或

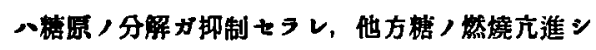

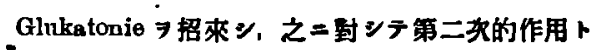
シテ肝，Glykogenolyse高マルモ,ト解スル 當ナリト信ズ.

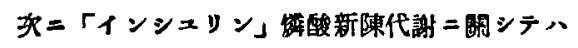
如何ト云フニ「インシュリン」注射ニヨリ正常及 ビ榶层病個铻二於テ血液中，無機烧酸監量及ビ之

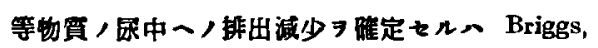
Koechig, Doisy u. Weber ${ }^{55)}$, Harrop u. Benedict ${ }^{56)}$, Staub, Günther u. Fröhlich ${ }^{67)}$, Wigglesworth, Woodrow, Smith u. Winter ${ }^{58)}$, Batherwiok, Bell n. Hill59), Katryama a. Killian60), 西元商简 ${ }^{16}$,

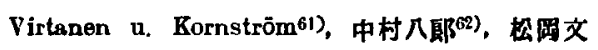
$七^{63)}$ ，諸氏ナリ．楌中松岡氏ハ「インシニリン」注

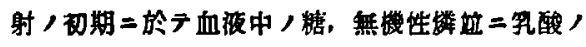

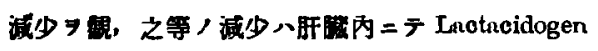
，合成更二淮デ榙原合成，篇メナラント云ーリ.
上述 Barrop u. Benedict 氏ハ「インシンyン」 a) Hexosephosphorsăure，如 * Phosphor 含

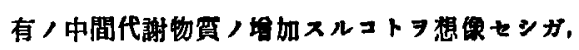
Audova u. Wagner ${ }^{64)}$ 兩氏ハ「インンニリン」ニ

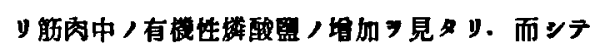

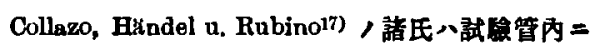
テ肪肉弹 (Muskelbrei) $=$ 「インシュリン」ヨ注加

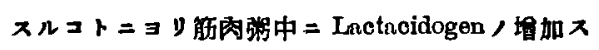
ルョ看タリ. Brugseh n. Horster 氏ハ「インッン リン」, Phosphatese , Aktivator タナスコトワ見 「インシニリン」ンHexosephosphorsature，生成 7 助長ン糖原/合成 7 促進スルト.Virtanen ${ }^{66)}$ 氏八 「インシニリン」, Milohstiurebakterien / Cooymnse (Coenzyme) $\Rightarrow$ 補フ點ヨy「インシュyン」N

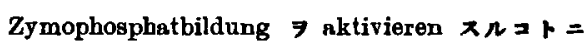

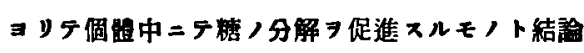
セり, 其ノ壀左トシテ「インシスリン」ニ 中， freies Phosphat 減少=学酸畤加入卜. 寺田 ${ }^{26)}$ 氏ハ「インンュリン」ニヨy家兔，四肢白色胼，䏦

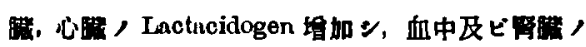
ソレッ減少セル 7 覞祭セリ. 中村25) 氏 垔「インシニソン」八解肉中，Lactucidogen，

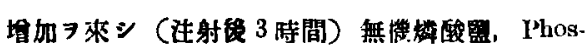
phugenphosphat ハ減少スト.

Cori67) 氏ハ最近 Embden u. Jost 氏，方法ニテ 肠肉內, Lactnoidogen 7 測定セル $=$, Rutte $=\Gamma 1$ ンシュリン」注射掼 1-11/2時間ニシテ Laotacidogen

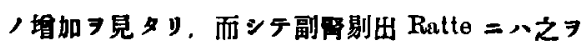

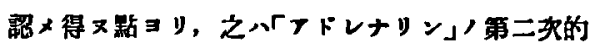
作用ナリト結諭セり. 又 Rntte 注射後旎肉中，糖原，坦加习來サズシテ反ッテ減 少ヨ來セリ．次ニ「インシニリン」ト血中乳酸䠄卜 ，躍孫八如何ト云フ = Briggs u. Miturbeiter ${ }^{56)}$ 氏 等以來多り，業縝「リ。 Lawnozek ${ }^{68)}$ 氏八犬及ビ 砣尿病患者二於テ「インシュリン」生射盀血中， 


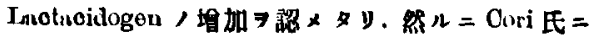
ヨレハ猫、犬、家鬼等二於テ「インシュリン」注射 ワナ女ル時 hypoglyklimische Krimpfe，起ラザ ル前二八血胙中，乳酸量ハ不签化ナリシト，即チ
Colluzo 11. Isewickinit) 氏, Kaw'umnratn) 氏等，報告 セル如っ「インシュリン」泩射二ヨn血中乳酸量，

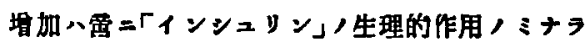
ズ，1ッ，中毒作用ナリト信ゼラル．

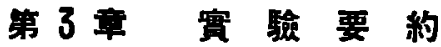

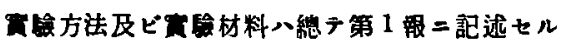

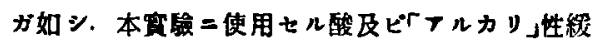

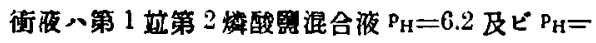
8.2 ノモノナリ. 又使用「ナドレナリン」ハ三共制 1000 倍溶液 $=シ テ$ 家鬼各頭其，0.2 或、 $0.3 \mathrm{cc} 7$ 背部皮下二过射セり、「インシュリン」ハ「トロン
卜」製 7 體重 $1 \mathrm{~kg}=$ 付 $\neq 1$ 單位, 割合 $=耳$ 蹊标內

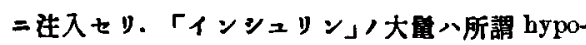
glykämische Krampf $\exists$ 招來 $シ$, 其'生理的作用 ヨ突知スル二適セザルガ故二常二少量 7 注射スル コトトセり。

\section{第 4 革 實 驗 成 綪}

第 1 節 「アドレナリン」注射成䅡

第 1 項「「ドレナリン小㚌獨律的

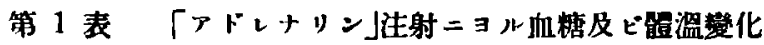

\begin{tabular}{|c|c|c|c|c|c|}
\hline 經 過 & 室温 & 體溫 & \multicolumn{2}{|c|}{ 血榶冒買減爽 } & 考 \\
\hline 注 射 前 & $\begin{array}{r}0 \\
12.0^{\circ}\end{array}$ & $\begin{array}{r}0 \\
38.8^{\circ}\end{array}$ & $\underset{125}{\mathrm{mg} \%}$ & \%o & \\
\hline 秘／4時間 & 12.0 & - & 132 & +6 & 閔重 $2000 \mathrm{~g}$ \\
\hline$I_{2}$ & 12.5 & 38.6 & 150 & +20 & $\Gamma \succ \jmath .3 \mathrm{cc}$ \\
\hline 1 & 12.5 & 38.2 & 232 & +86 & 皮下注射 \\
\hline $11 / 2$ & 12.5 & - & 264 & +111 & \\
\hline 2 & 13.0 & 38.0 & 262 & +110 & \\
\hline 3 & 13.0 & 38.0 & 226 & +80 & \\
\hline 4 & 14.0 & 38.1 & 168 & +34 & \\
\hline 5 & 14.0 & 38.0 & 115 & -8 & \\
\hline
\end{tabular}

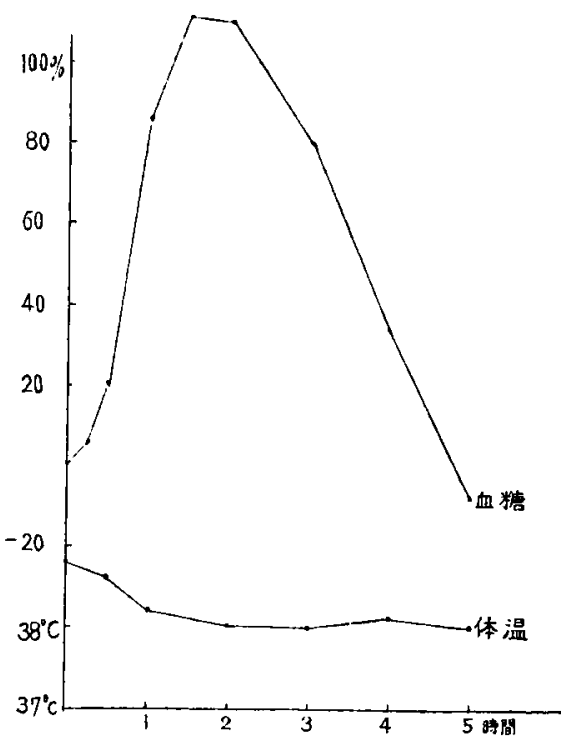




\begin{tabular}{|c|c|c|c|c|c|}
\hline 砫 聥 & 室温 & 组盢 & 血精害 & 塤減䍜 & 考 \\
\hline 注射的 & $\begin{array}{r}0 \\
10.5^{\circ}\end{array}$ & $\begin{array}{r}C \\
38.8^{\circ}\end{array}$ & $\begin{array}{c}\mathrm{mg} \% \\
95\end{array}$ & $\%$ & \multirow{9}{*}{$\begin{array}{l}\text { 售重 } 2150 \mathrm{~g} \\
\Gamma\ulcorner, 0.2 \mathrm{cc} \\
\text { 皮下注射 }\end{array}$} \\
\hline 段 $1 / 4$ 時間 & 10.5 & - & 106 & +6 & \\
\hline $1 / 2$ & 11.0 & 38.5 & 129 & +30 & \\
\hline 1 & 12.0 & 38.6 & 170 & +71 & \\
\hline $14 / 2$ & 12.5 & 38.7 & 184 & +89 & \\
\hline 2 & 13.0 & 38.8 & 191 & +92 & \\
\hline 3 & 14.0 & 39.0 & 199 & +100 & \\
\hline 4 & 15.0 & 39.1 & 170 & +71 & \\
\hline 5 & 16.0 & 39.1 & 113 & +14 & \\
\hline
\end{tabular}

松井，井上"0)兩氏八家鬼に「フドレナリン」1.0ce $(1: 1000) \ni$ 皮下注射後 2-3 時間ニシテ血榙量最 高トナリ 6 時間ニシテ平常値トナリ、8-10 時間

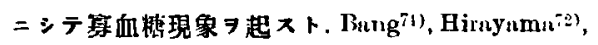

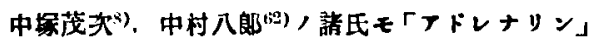

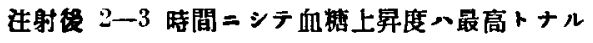

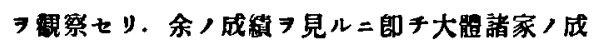

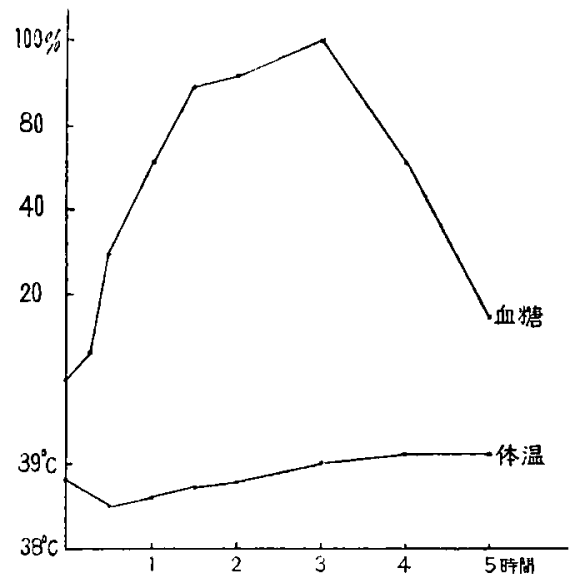

程ト一致シ 1 時間牛或ハ 3 時間ニシテ最高值 $ヨ$ 示 セリ、上昇度心注射勧卜平行セル

「テドレナリン」0.3 $\mathrm{c}=$ ニン多少，體溫，下降 э示スモり多》, $0.2 \mathrm{cc}=5$ ，最初1時間位迄、下 降スルモ役上苌，倾向习來スモ，多シ・然レドモ 何レモ著シキ能溫ノ變動

\section{第 2 項「アドレナリン」及ビ「アルカリ性䌅衝液合併注射}

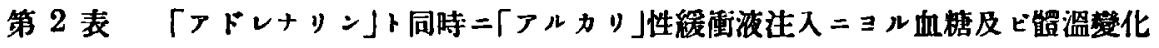

\begin{tabular}{|c|c|c|c|c|c|}
\hline 經 過 & 室溫 & 體溫 & 血煏冒 & 增減率 & 倩 \\
\hline 注射的 & $12.0^{\circ}$ & $38.4^{\circ}$ & $\begin{array}{l}\mathrm{mg} \% \\
111\end{array}$ & $\%$ & \\
\hline 役每 $/ 2$ 時間 & 13.0 & 38.6 & 166 & +50 & 能重2000 g \\
\hline 1 & 13.0 & 38.7 & 168 & +51 & 悢衝夜 $\mathrm{P}_{\mathrm{H}} 8.201$ \\
\hline $1 / 2$ & 14.0 & 39.4 & $! 73$ & +56 & $15 \mathrm{co}$ 靜豚內注入 \\
\hline 2 & 14.0 & 39.3 & 197 & +77 & $\Gamma>, 0.2 \mathrm{cc}$ \\
\hline 3 & 14.0 & 39.3 & 173 & +56 & 皮下注射 \\
\hline 4 & 14.0 & 39.1 & 141 & +27 & \\
\hline 5 & 14.0 & 38.9 & 120 & +8 & \\
\hline
\end{tabular}

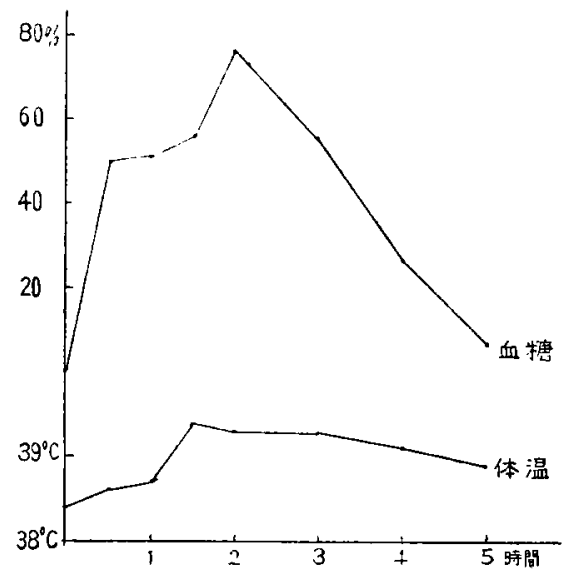




\begin{tabular}{|c|c|c|c|c|c|c|}
\hline 經 週 & 宣温 & 呾谓 & 血糖單 & 增娍率: & 備 & 考 \\
\hline 注 射 前 & $14.0^{\circ}$ & ${ }_{38.3^{\circ}}$ & $\begin{array}{c}\mathrm{mg} \% \\
111\end{array}$ & $\%$ & \multirow{2}{*}{\multicolumn{2}{|c|}{ 䁬垂 $2210 \mathrm{~g}$}} \\
\hline 级哠間 & 14.0 & 38.4 & 143 & +29 & & \\
\hline 1 & 14.0 & 38.6 & 145 & +31 & \multicolumn{2}{|l|}{ 缓街花 $10 \mathrm{oc}$} \\
\hline $1 \% \frac{1}{2}$ & 14.0 & 38.6 & 152 & +36 & \multicolumn{2}{|l|}{ 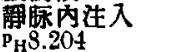 } \\
\hline 2 & 14.0 & 38.5 & 154 & +39 & \multirow{2}{*}{\multicolumn{2}{|c|}{$[\supset\lrcorner^{\circ} .2 \mathrm{cc}$}} \\
\hline 3 & 14.5 & 38.6 & 150 & +25 & & \\
\hline 4 & 15.0 & 38.4 & 134 & +21 & \\
\hline 5 & 15.0 & 38.4 & 131 & +18 & & \\
\hline
\end{tabular}

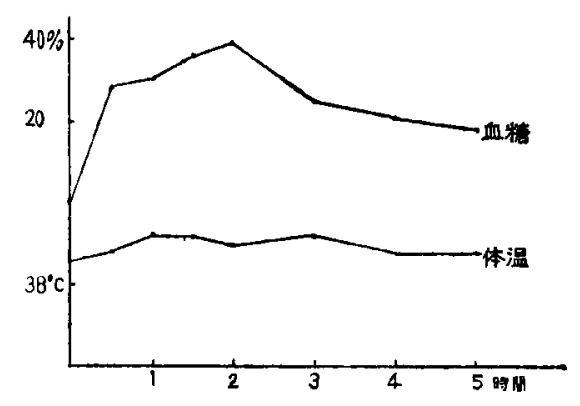

\begin{tabular}{|c|c|c|c|c|c|}
\hline 脞 過 & 室溫 & 體溫 & 血桾量 & 增減率 & 備 \\
\hline 生射期 & 11.0 & 38.8 & $\begin{array}{l}\mathrm{mg} \% \\
102\end{array}$ & $\%$ & \multirow[b]{2}{*}{ 體重 $2100 \mathrm{~g}$} \\
\hline 级慜 $1 / 2$ 时間 & 12.0 & 39.3 & 175 & +72 & \\
\hline 1 & 12.0 & 39.5 & 190 & +86 & \multirow{3}{*}{ 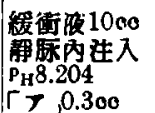 } \\
\hline $11 / 2$ & 12.0 & 39.8 & - & - & \\
\hline 2 & 12.5 & 39.5 & .172 & +69 & \\
\hline 3 & 13.0 & 39.3 & 134 & +31 & \multirow[t]{2}{*}{ 皮下注射 } \\
\hline 4 & 14.0 & 39.0 & 108 & +6 & \\
\hline 5 & 15.0 & 38.5 & 101 & -1 & \\
\hline
\end{tabular}

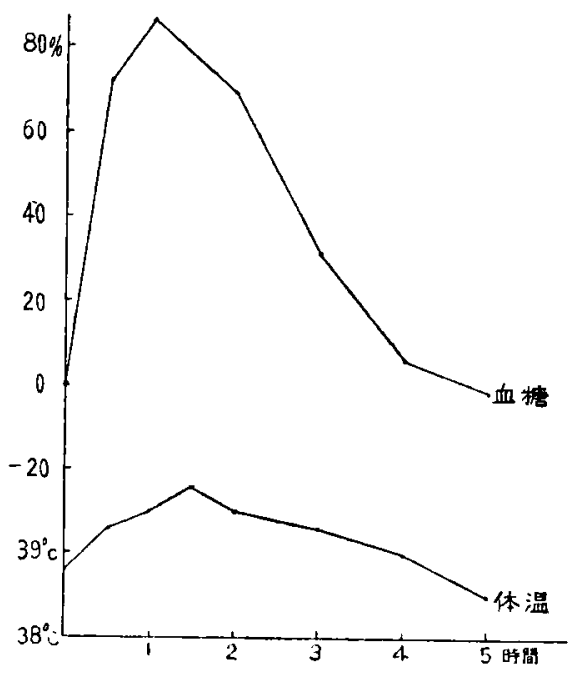

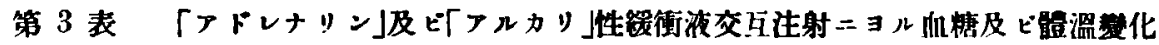

「ナドレナリン」住射得 1 時間紘衙液珄入

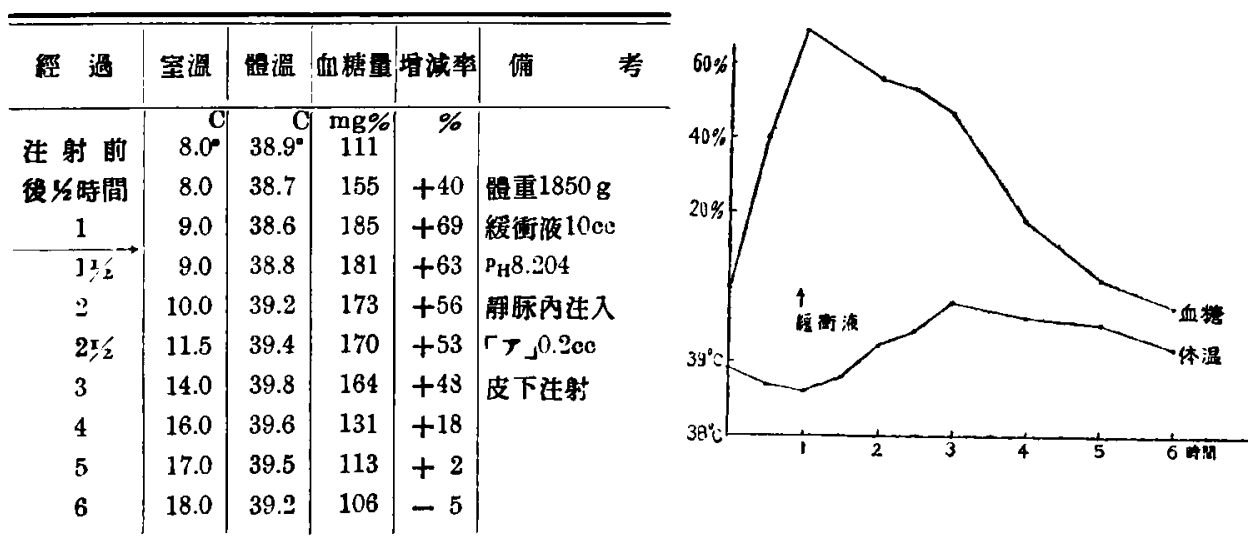




\begin{tabular}{|c|c|c|c|c|c|}
\hline 經 過 & 室溫 & 咆盢 & 血楼量 & 整減率 & 考 \\
\hline 青射曾 & $\begin{array}{r}0 \\
11.5 \\
12.0 \\
13.0\end{array}$ & $\begin{array}{r}\text { ( } \\
38.7^{\circ} \\
38.7 \\
39.3\end{array}$ & $\begin{array}{c}\mathbf{m g \%} \\
124 \\
120 \\
119\end{array}$ & $\begin{array}{r}\% \\
-3 \\
-4\end{array}$ & 雵重 $2500 \mathrm{~g}$ \\
\hline $\begin{array}{l}11 / 2 \\
2 \\
21 / 2 \\
3 \\
4 \\
5 \\
6 \\
7\end{array}$ & $\begin{array}{l}14.0 \\
16.0 \\
17.0 \\
17.0 \\
18.0 \\
18.0 \\
18.0 \\
17.0\end{array}$ & $\begin{array}{l}39.0 \\
39.0 \\
39.0 \\
38.8 \\
38.8 \\
38.7 \\
38.7 \\
38.7\end{array}$ & $\begin{array}{l}150 \\
163 \\
164 \\
170 \\
177 \\
164 \\
154 \\
137\end{array}$ & $\begin{array}{l}+21 \\
+31 \\
+32 \\
+37 \\
+43 \\
+32 \\
+24 \\
+6\end{array}$ & $\begin{array}{l}\text { 翻內这射 } \\
\mathrm{P}_{\mathrm{H}} 8.204 \\
\boldsymbol{T} 0.2 \mathrm{cc} \\
\text { 友下泩射 }\end{array}$ \\
\hline
\end{tabular}

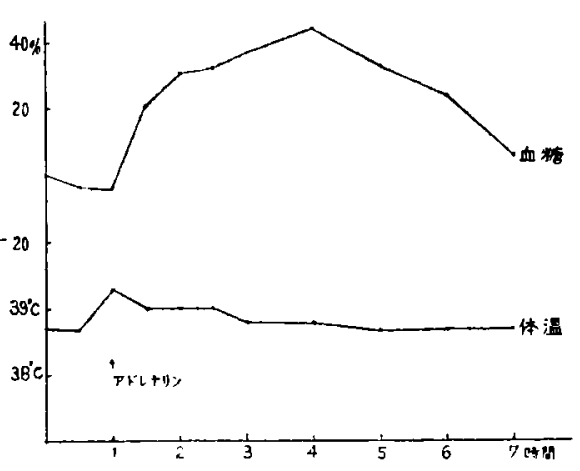

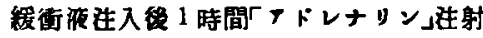

\begin{tabular}{|c|c|c|c|c|c|}
\hline 絓 過 & 宔㯰 & 胆溫 & 血糟量 & 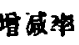 & 蔽 \\
\hline 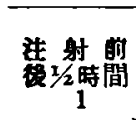 & $\begin{array}{r}\mathbf{C} \\
11.5^{\circ} \\
12.0 \\
13.0\end{array}$ & $\begin{array}{r}\mathbf{C} \\
38.6^{\circ} \\
38.8 \\
38.5\end{array}$ & $\begin{array}{c}\text { mg\% } \\
115 \\
124 \\
117\end{array}$ & $\begin{array}{r}\% \\
+\quad 8 \\
+\quad 2\end{array}$ & 用重 $2200 \mathrm{~g}$ \\
\hline $\begin{array}{l}11 / 2 \\
2 \\
2 x / 2 \\
3 \\
4 \\
5 \\
6 \\
7\end{array}$ & $\begin{array}{l}14.0 \\
16.0 \\
17.0 \\
17.0 \\
18.0 \\
18.0 \\
18.0 \\
17.0\end{array}$ & $\begin{array}{l}38.6 \\
38.6 \\
39.0 \\
39.3 \\
39.3 \\
39.0 \\
38.9 \\
38.9\end{array}$ & $\begin{array}{l}129 \\
154 \\
155 \\
161 \\
166 \\
155 \\
154 \\
131\end{array}$ & $\begin{array}{l}+12 \\
+34 \\
+35 \\
+40 \\
+44 \\
+35 \\
+34 \\
+14\end{array}$ & 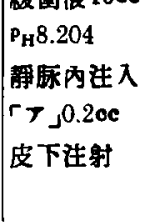 \\
\hline
\end{tabular}

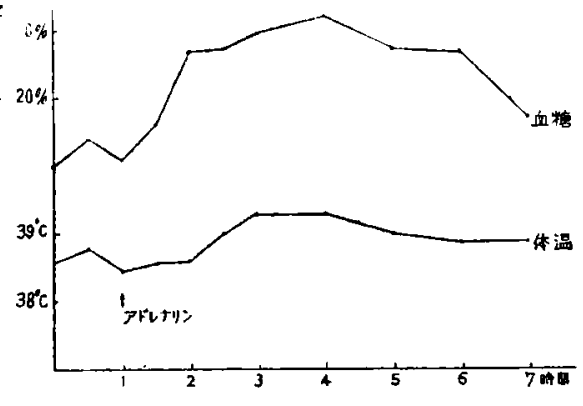

象，抑制サルル 見ル.之八斯述 Underhill, Elins, ト大差ナシ・咀溫八相富上昇スレドも一般二第 1

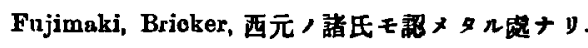

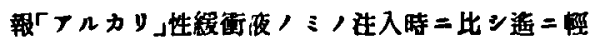
度ニシテ, 且持悢時間短シ。

過血糖持特間ハ「フドレナリン」單㯰注射/揭合

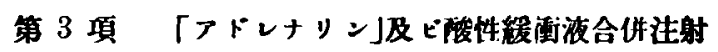

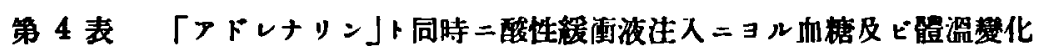

\begin{tabular}{|c|c|c|c|c|c|}
\hline 經 過 & 窐溫 & 能溫 & 血糖箸 & 冾减华 & 侢 \\
\hline 玨射前 & $\begin{array}{r}\mathrm{C} \\
8.0^{\circ}\end{array}$ & $38.1^{\circ}$ & $\begin{array}{c}\mathrm{mg} \% \\
102\end{array}$ & $\%$ & \multirow[b]{2}{*}{ 䡒重 $1600 \mathrm{~g}$} \\
\hline 役原時间 & 9.0 & 37.7 & 182 & +78 & \\
\hline 1 & 11.0 & 38.3 & 197 & +93 & 䌅街源 1000 \\
\hline $11 / 2$ & 11.5 & 38.6 & 179 & +75 & $\mathrm{P}_{\mathrm{H}} 6.203$ \\
\hline 2 & 13.0 & 38.8 & 166 & +63 & \multirow{3}{*}{$\begin{array}{l}\text { 用豚內注入 } \\
\text { 「ナ」0.3co } \\
\text { 皮下泩射 }\end{array}$} \\
\hline 3 & 14.0 & 38.7 & 146 & +43 & \\
\hline 4 & 15.0 & 38.6 & 150 & +47 & \\
\hline 5 & 16.0 & 38.6 & 161 & +58 & \\
\hline 6 & 15.0 & 38.8 & 127 & +25 & \\
\hline
\end{tabular}

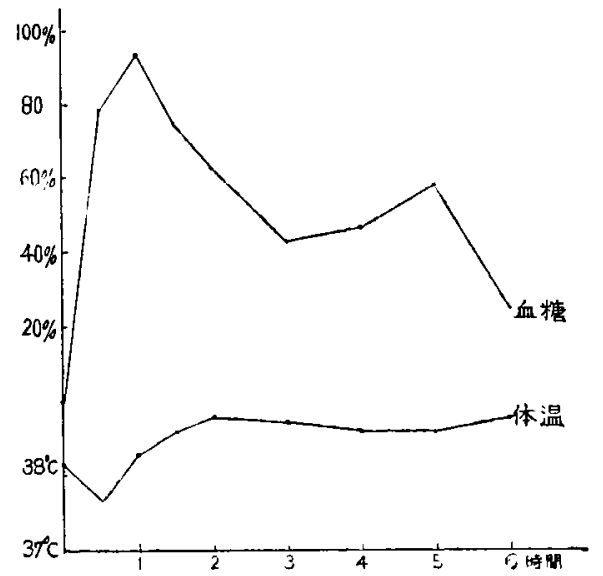




\begin{tabular}{|c|c|c|c|c|c|}
\hline 經 過 & 室溫 & 湦温 & 血燃量 & 增做率 & 考 \\
\hline 过射前 & $\begin{array}{r}\mathrm{C} \\
8.0^{\circ}\end{array}$ & $\begin{array}{r}\mathbf{C} \\
39.0^{\circ}\end{array}$ & $\begin{array}{c}\mathbf{m g} \% \\
113\end{array}$ & $\%$ & \multirow[b]{2}{*}{ 顝重 $1550 \mathrm{~g}$} \\
\hline 啳为時間 & 10.0 & 39.3 & 199 & +76 & \\
\hline 1 & 11.5 & 39.8 & 226 & +100 & 級衝夜 $10 \mathrm{cc}$ \\
\hline 112 & 13.0 & 39.7 & 204 & +81 & $\mathrm{P}_{\mathrm{H}} 6.203$ \\
\hline 2 & 14.0 & 39.1 & 186 & +64 & 静阥内注入 \\
\hline 3 & 14.0 & 38.8 & 168 & +49 & $\Gamma>\lrcorner 0.2 \mathrm{co}$ \\
\hline 4 & 15.0 & 38.5 & $13 I$ & +16 & 皮下注射 \\
\hline 5 & 16.0 & 38.8 & 119 & +5 & \\
\hline 6 & 15.0 & 38.8 & 106 & -6 & \\
\hline
\end{tabular}

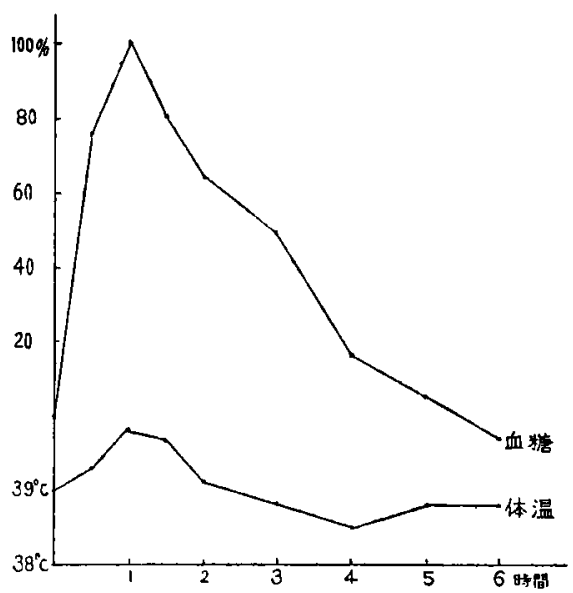

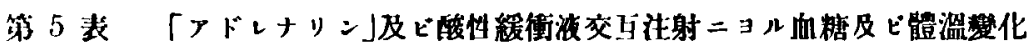

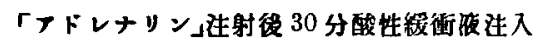

\begin{tabular}{|c|c|c|c|c|c|}
\hline 經 過 & 室溫 & 能溫 & 血糖量 & 埥珢本 & 考 \\
\hline 注射 前 & $\mathbf{6 . 0}^{\mathbf{C}}$ & $38.0^{\circ}$ & $\begin{array}{c}\mathrm{mg \%} \\
106\end{array}$ & $\%$ & \\
\hline 啳不時間 & 7.0 & 38.0 & 155 & +46 & 能重 $1930 \mathrm{~g}$ \\
\hline 1 & 8.0 & 38.1 & 248 & +136 & 䋧衙夜 $10 \mathrm{cc}$ \\
\hline $11 / 2$ & 9.0 & 38.7 & 264 & +149 & $\mathbf{P}_{\mathrm{H}} 6.203$ \\
\hline 2 & 10.0 & 38.5 & 260 & +145 & 解柰內注入 \\
\hline 3 & 12.0 & 38.6 & 250 & +136 & $r_{\gamma_{j}} 0.2 \mathrm{cc}$ \\
\hline 4 & 13.0 & 38.7 & 201 & +90 & 皮下注射 \\
\hline 5 & 13.0 & 38.5 & 144 & +36 & \\
\hline 6 & 13.0 & 38.2 & 95 & -10 & \\
\hline
\end{tabular}

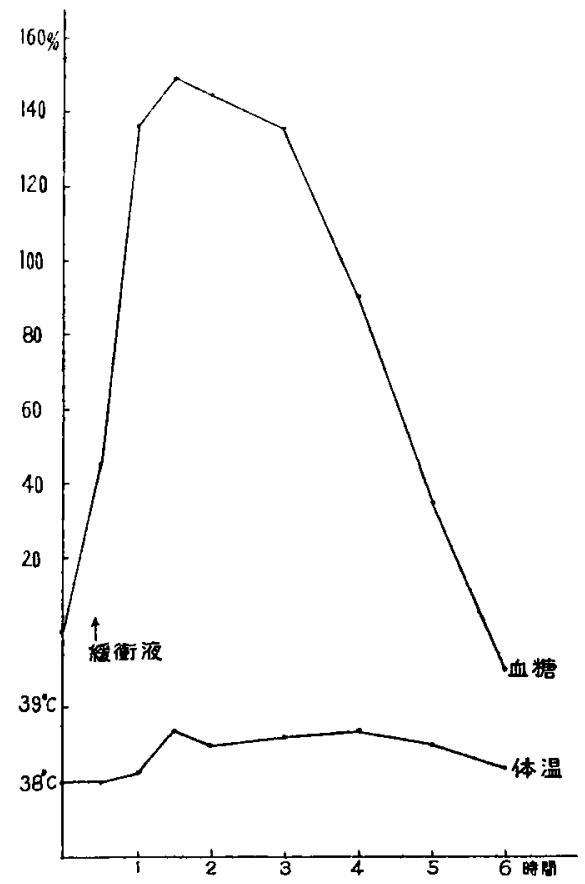




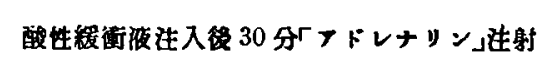

\begin{tabular}{|c|c|c|c|c|c|}
\hline 积＼cjkstart過 & 室调 & 䯠温 & 如楼量 & 㙋減率 & 考 \\
\hline 注射前 & $\begin{array}{r}4 \\
6.0^{\circ}\end{array}$ & $\begin{array}{r}\mathrm{C} \\
38.3^{\circ}\end{array}$ & $\begin{array}{c}\mathrm{mg} \% \\
104\end{array}$ & $\%$ & \\
\hline 後1/2時間 & 7.0 & 38.5 & 117 & +13 & 蹧重 $1800 \mathrm{~g}$ \\
\hline 1 & 8.0 & 39.0 & 175 & +68 & 緩街液 $10 \mathrm{ccc}$ \\
\hline $1 \pi / 2$ & 9.0 & 39.3 & 247 & +138 & $\mathbf{P}_{\mathbf{H}} 6.203$ \\
\hline 2 & 10.0 & 39.1 & 234 & +125 & 静腺內这入 \\
\hline 3 & 12.0 & 39.0 & 280 & +169 & $\left.r_{\top}\right\lrcorner 0.2 \mathrm{ce}$ \\
\hline 4 & 13.0 & 38.8 & 266 & +156 & 皮下注射 \\
\hline 5 & 13.0 & 38.5 & 217 & +109 & \\
\hline 6 & 130 & 38.5 & 138 & +33 & \\
\hline
\end{tabular}

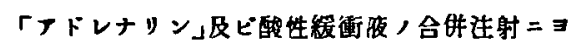
リ過血楼ハ抑制サレザルモ, 最高值ヨ示スハ「ア

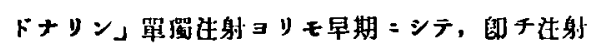
後 1 時間既二最高值二達スルモノ多シ。「アドレ

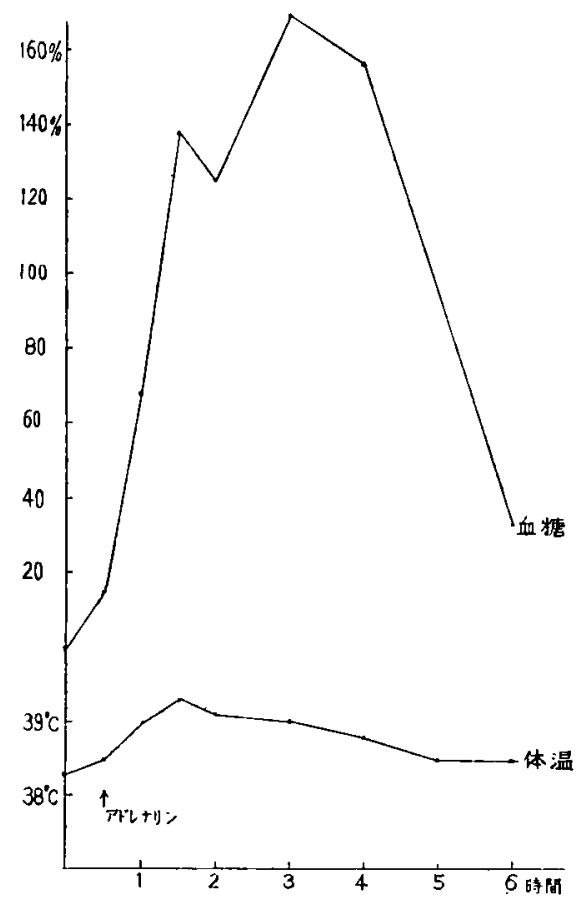

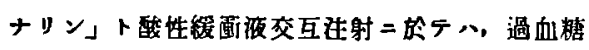
現象ノ相當著明二堵强サレタルョ䁫祭セり。

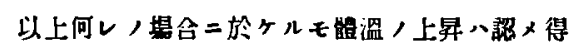
レトモ螕テ諲微ナリ。

\section{第二節「「ィンシュリン注射成䋶 \\ 第 1 項 $「$ 「ンシーリン」單䖽注射}

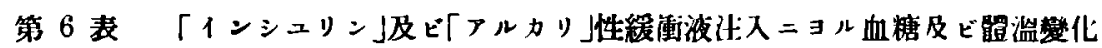

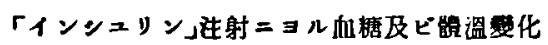

\begin{tabular}{|c|c|c|c|c|c|}
\hline 經＼cjkstart過 & 室溫 & 触溫 & 血粕量 & 堵減率 & 宩 \\
\hline 过射 期 & $15.0^{\circ}$ & $\begin{array}{r}\mathrm{C} \\
38.4^{\circ}\end{array}$ & $\begin{array}{c}\text { mg\% } \\
117\end{array}$ & $\%$ & \multirow{10}{*}{ 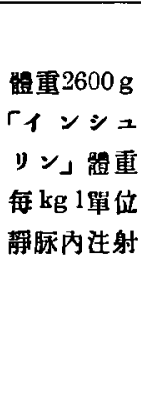 } \\
\hline 待 $1 / 4$ 間 & 16.0 & 38.1 & 93 & -20 & \\
\hline$y$ & 16.0 & 37.8 & 65 & -44 & \\
\hline 1 & 16.0 & 37.7 & 47 & -60 & \\
\hline $1 \frac{1}{2}$ & 16.0 & 37.3 & 52 & -56 & \\
\hline 2 & 16.0 & 37.3 & 56 & -52 & \\
\hline 3 & 17.0 & 38.0 & 77 & -34 & \\
\hline 4 & 17.0 & 38.3 & 97 & -17 & \\
\hline 5 & 17.0 & 38.6 & 104 & -11 & \\
\hline 6 & 16.0 & 38.4 & 1111 & -5 & \\
\hline
\end{tabular}

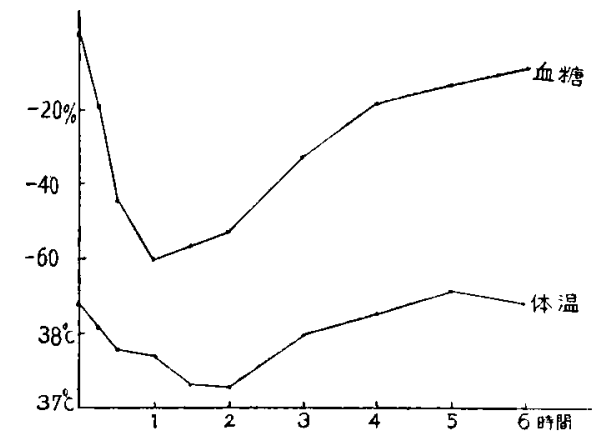


「インシュリン」ト同時ニ「ナルカり」性

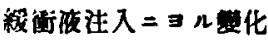

\begin{tabular}{|c|c|c|c|c|c|}
\hline 柕，過 & 室㴓 & 咀䁅 & 血糖 & 增搌率 & 考 \\
\hline 这射前 & $\begin{array}{r}\mathrm{C} \\
15.0^{\circ}\end{array}$ & $390^{\circ}$ & $\begin{array}{c}\mathrm{mg} \% \\
108\end{array}$ & $\%$ & \\
\hline 积1/4時間 & 16.0 & 39.1 & 75 & -31 & 能重 $2600 \mathrm{~g}$ \\
\hline $1 / 2$ & 16.0 & 39.5 & 72 & -33 & 「インンュ \\
\hline 1 & 16.0 & 39.5 & 43 & -60 & ンン」體重 \\
\hline $11 / 2$ & 16.0 & 39.8 & 43 & -60 & 敏 $\mathrm{kg}$ 1單位 \\
\hline 2 & 16.0 & 39.9 & 61 & -44 & 静䐂內过射 \\
\hline 3 & 17.0 & 40.3 & 66 & -39 & 悢街夜 $100 \mathrm{co}$ \\
\hline 4 & 17.0 & 40.5 & 99 & -8 & $\mathbf{p}_{\mathrm{H}} 8.204$ \\
\hline 5 & 17.0 & 39.8 & 93 & -14 & 靜豚內生入 \\
\hline 6 & 16.0 & 39.4 & $10 t$ & -4 & \\
\hline
\end{tabular}

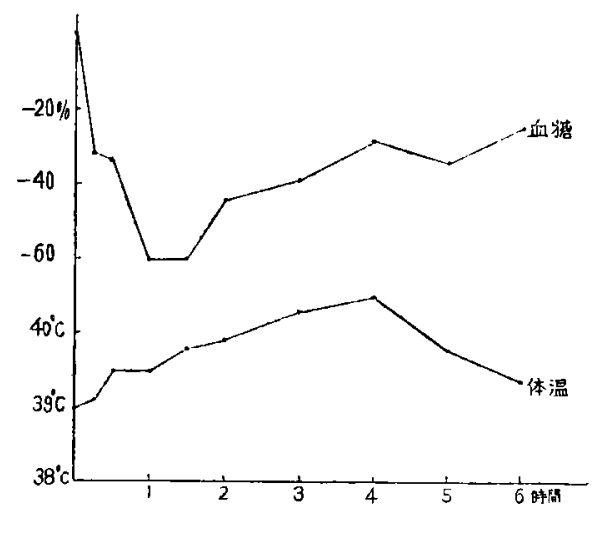

「インシュリン」ト同時ニ「マルカり」性

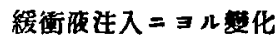

\begin{tabular}{|c|c|c|c|c|c|}
\hline 踝 過 & 宔溫 & 體温 & 血糖国 & 增減苧 & 考 \\
\hline 注 射 甫 & $\begin{array}{r}\mathrm{C} \\
15.0^{\circ}\end{array}$ & $\begin{array}{r}\mathrm{C} \\
38.9^{\circ}\end{array}$ & $\begin{array}{c}\mathrm{mg} \% \\
113\end{array}$ & $\%$ & \\
\hline 陆 $1 / 4$ 時間 & 16.0 & 39.0 & 106 & -6 & 葄重 $2300 \mathrm{~g}$ \\
\hline$y_{2}^{\prime}$ & 16.0 & 39.5 & 81 & -28 & 「インシュ \\
\hline 1 & 16.0 & 40.2 & 68 & -47 & ソン」䯏重 \\
\hline $11 / 2$ & 16.0 & 40.2 & 59 & -48 & 毎 kg 1單位 \\
\hline 2 & 16.0 & 40.1 & 75 & -34 & 静豚内注射 \\
\hline 3 & 17.0 & 40.5 & 102 & -10 & 释街液 $10 \mathrm{cc}$ \\
\hline 4 & 17.0 & 40.4 & 106 & -6 & $P_{H} 9.204$ \\
\hline 5 & 17.0 & 39.8 & 111 & -2 & 静豚内注射 \\
\hline 6 & 16.0 & 39.3 & 113 & 0 & \\
\hline
\end{tabular}

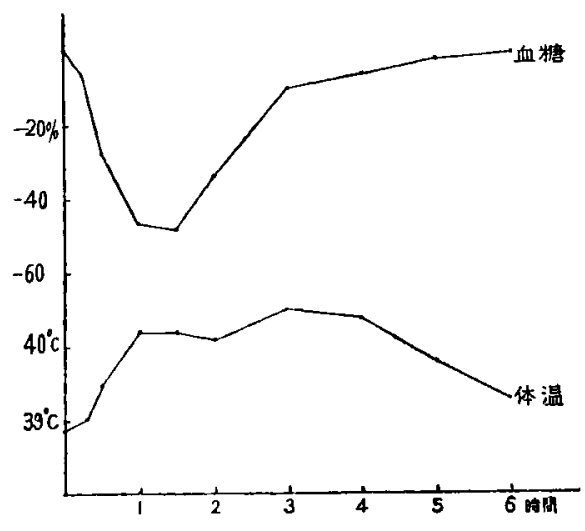

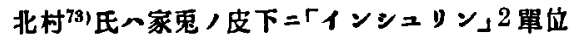

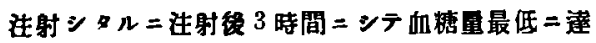
シ， 6 時間 ニシテ注射前二復鼠シタ几モ，其，減 少事ハ必ズシモー定セズト. Wiecowski74), 艮谷 川75)，小室(6)，諸氏ハ「インシュリン」注射後 23 時間 シンテ最低二洋シタルョ見タリ. 秋谷 ${ }^{77)}$ 氏

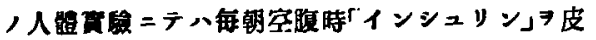
下二拄射 スルー1一2時間ニシテ最低トナリ $0.05 \%$ 


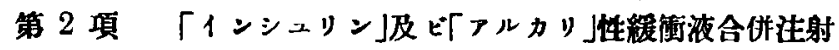

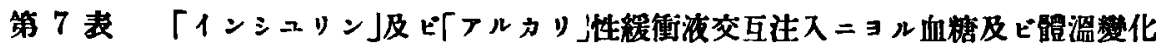

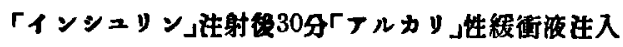

\begin{tabular}{|c|c|c|c|c|c|}
\hline 經 週 & 室溫 & 顝溫 & 血糖量 & 增減茲 & 考 \\
\hline 注射前 & $\begin{array}{r}\mathrm{C} \\
11.5^{\circ}\end{array}$ & ${ }_{39.0^{\circ}}^{\mathrm{C}}$ & $\begin{array}{c}\mathrm{mg} \% \\
108\end{array}$ & $\%$ & \multirow{3}{*}{ 䝑审 $2050 \mathrm{~g}$} \\
\hline 後紧時间 & 12.0 & 39.1 & 113 & +5 & \\
\hline $1 / 2$ & 13.0 & 38.8 & 54 & -50 & \\
\hline 1 & 13.0 & 39.3 & 65 & -40 & リン」䯏重 \\
\hline - $11 / 2$ & 13.0 & 39.8 & 66 & -39 & 毎 kg 1單位 \\
\hline 2 & 14.0 & 39.7 & 92 & -15 & 静脉內注入 \\
\hline 3 & 14.0 & 39.7 & 110 & +2 & 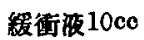 \\
\hline 4 & 15.0 & 39.5 & 105 & -3 & $\mathrm{P}_{\mathrm{H}} 8.204$ \\
\hline 5 & 15.0 & 39.1 & 110 & +2 & 静豚內注入 \\
\hline
\end{tabular}

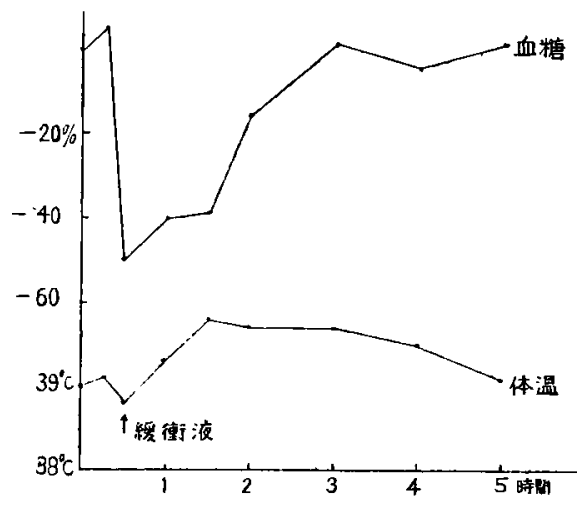

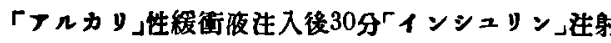

\begin{tabular}{|c|c|c|c|c|c|}
\hline 經 過 & 室溫 & 能温 & 血糖娾 & 㙕減本 & 㤗 \\
\hline 注射 榭 & $10.5^{\circ}$ & $\begin{array}{r}\mathbf{C} \\
38.0^{\circ}\end{array}$ & $\begin{array}{l}\mathrm{mg} \% \\
117\end{array}$ & $\%$ & \multirow[b]{2}{*}{ 唱電 $1970 \mathrm{~g}$} \\
\hline 盽 $1 / 4$ 時間 & 13.0 & 38.3 & 119 & +2 & \\
\hline$y / 2$ & 13.0 & 38.6 & 115 & -2 & 「インシュ \\
\hline 1 & 13.0 & 39.4 & 75 & -36 & リン」销重 \\
\hline $1^{1 / 2}$ & 13.0 & 39.5 & 68 & $-4 i$ & 毎 kg 1單位 \\
\hline 2 & 14.0 & 39.5 & 81 & -31 & 䣡暞內这射 \\
\hline 3 & 14.0 & 39.8 & 110 & -6 & 紱衙液 $10 \mathrm{cc}$ \\
\hline 4 & 15.0 & 39.4 & 125 & +7 & $\mathrm{P}_{\mathrm{H}} 9.204$ \\
\hline 5 & 15.0 & 39.1 & 119 & +2 & 静豚內注射 \\
\hline
\end{tabular}

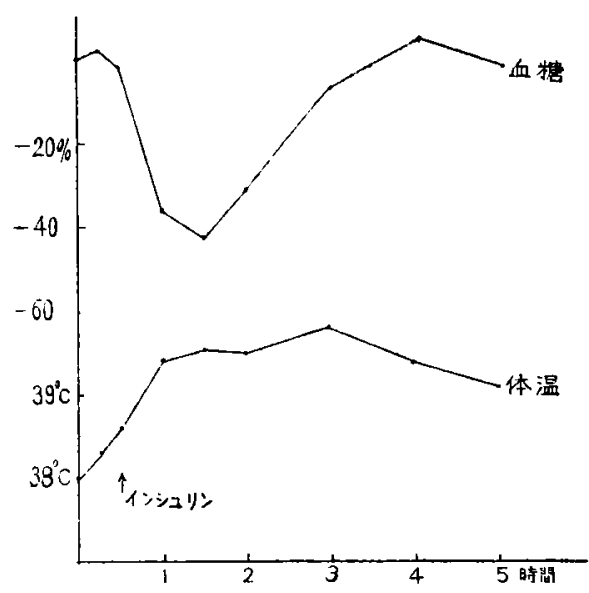

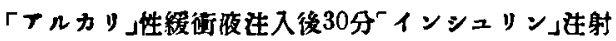

\begin{tabular}{|c|c|c|c|c|c|}
\hline 經＼cjkstart週 & 室温 & 顝溫 & 血糖量 & 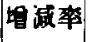 & 考 \\
\hline 注 射 首 & $11.0^{\circ}$ & $\begin{array}{r}\mathbf{C} \\
38.8^{\circ}\end{array}$ & $\begin{array}{c}\mathrm{mg} \% \\
117\end{array}$ & $\%$ & \\
\hline 徙不 $/ 4$ 時間 & 11.0 & 38.9 & 119 & +2 & 軆重 $2150 \mathrm{~g}$ \\
\hline $1 / 2$ & 12.0 & 39.1 & 110 & -1 & 紘疅液 $10 \mathrm{cc}$ \\
\hline 1 & 13.0 & 39.8 & 70 & -25 & $\mathrm{P}_{\mathrm{H}} 8.204$ \\
\hline $1 x / 2$ & 13.0 & 40.3 & 66 & -28 & 融豚內这入 \\
\hline 2 & 13.0 & 40.0 & 63 & -30 & 「インンニ \\
\hline 3 & 15.0 & 39.9 & 83 & -15 & シン」體重 \\
\hline 4 & 17.0 & 39.3 & 86 & -12 & 毎 $\mathrm{kg}$ 1單位 \\
\hline 5 & 17.0 & 39.0 & 111 & -5 & 郬脤内注射 \\
\hline
\end{tabular}

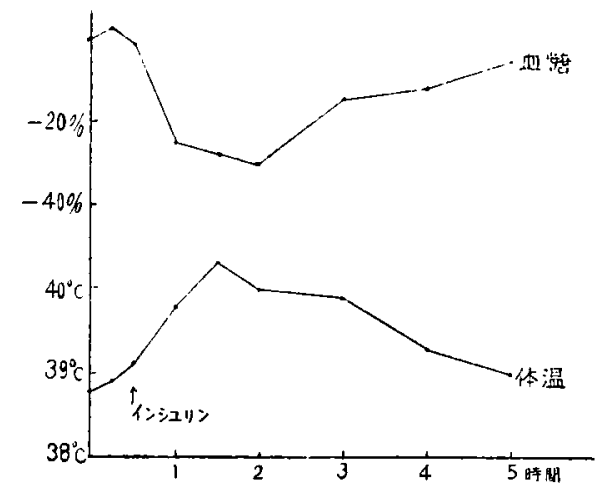


上表第 6 表第 2、第 3 及ビ第 7 表二示スガ如 ク，

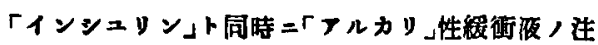

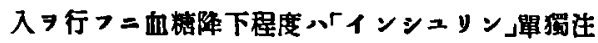
射提合ト大差ナシ. Mngenta \& Binsotti78) 氏八 「インンュリン」进射ニョリテ生ズル豈血糖，第 2

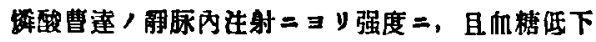

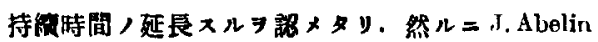

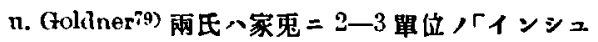
Уン」(Lilly) 7 注射シ 30 分後 $1.0 \mathrm{~g}$, Dinatrinm.

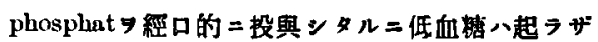

ルカ，或八著シク抑制せルルラ胃察セリ。

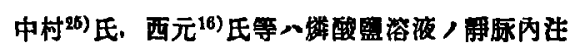

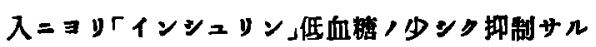

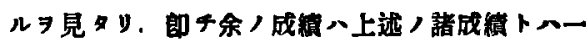

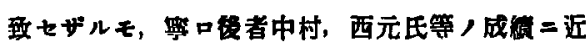
干感厂リ（第 6 表，第 3 测)。

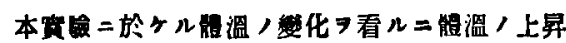

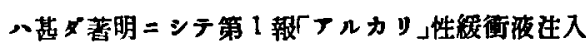

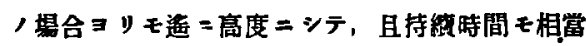

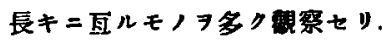

第 3 項「インシュリン」及ビ酸性緩重液合作注射

第 8 表「インシュリン」及ビ酸性䌅衝湤注入，血榶及ビ體溫湿化

\begin{tabular}{|c|c|c|c|c|c|}
\hline 經＼cjkstart副 & 室溫 & 梪温 & 血㷮量 & 堄減率 & 備 \\
\hline 注 射 前 & $\begin{array}{r}0 \\
9.0^{\circ}\end{array}$ & $\begin{array}{r}\mathrm{O} \\
38.1^{\circ}\end{array}$ & $\begin{array}{c}\mathrm{mg} \% \\
125\end{array}$ & $\%$ & \\
\hline 律功 $/ 2$ 時間 & 12.0 & 38.3 & 97 & -22 & 咀重 $2300 \mathrm{~g}$ \\
\hline 1 & 13.0 & 38.4 & 81 & -35 & $10 \mathrm{cc}$ 静豚风 \\
\hline $1 / 2$ & 14.0 & 38.8 & 79 & -37 & 「インシ \\
\hline 2 & 17.0 & 38.8 & 57 & -54 & ソン」體動 \\
\hline 3 & 18.0 & 39.2 & 83 & -34 & 敏 $\mathrm{kg}$ 1單位 \\
\hline 4 & 18.0 & 39.2 & 88 & -30 & 缓街夜 $10 \mathrm{ec}$ \\
\hline 5 & 18.0 & 39.3 & 84 & -33 & $P_{H} 6.203$ \\
\hline$t i$ & 17.0 & 39.2 & 99 & -21 & 静脉內注射 \\
\hline
\end{tabular}

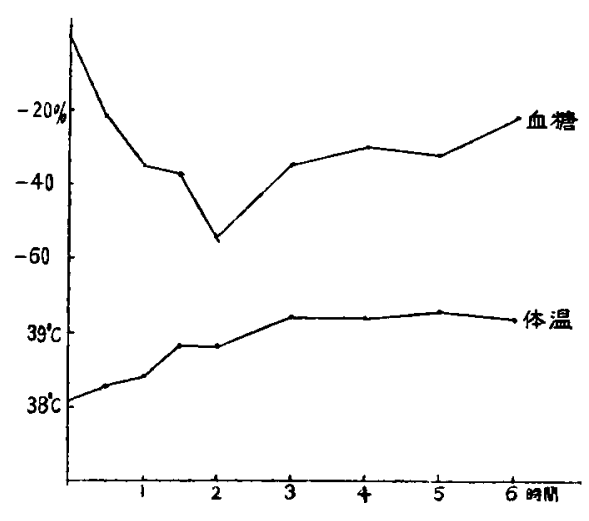

「インシュリン」注射掼 30 分酸性䌅重液泩入

\begin{tabular}{|c|c|c|c|c|c|}
\hline 經 過 & 室溫 & 䯏溫 & 血精量 & 目城率 & 考 \\
\hline 这射前 & $\begin{array}{r}\mathbf{C} \\
8.0^{\circ}\end{array}$ & $\begin{array}{r}. \mathrm{C} \\
39.0^{\circ}\end{array}$ & $\begin{array}{c}\mathrm{mg} \% \\
127\end{array}$ & $\%$ & \\
\hline 後1/2時間 & 9.0 & 38.8 & 43 & -66 & 能重 $2700 \mathrm{~g}$ \\
\hline 1 & 11.0 & 39.0 & 52 & -59 & 「インシュ \\
\hline $11 / 2$ & 13.0 & 39.3 & 70 & -45 & リン」栺重 \\
\hline 2 & 14.0 & 39.3 & 72 & -43 & 每 $\mathrm{kg}$ 1單位 \\
\hline 3 & 15.0 & 39.5 & 106 & -17 & 静豚內注入 \\
\hline 4 & 15.0 & 39.5 & 116 & -13 & 紘垔夜 $10 \mathrm{cc}$ \\
\hline 5 & 15.0 & 39.3 & 104 & -18 & $\mathbf{p}_{\mathrm{H}} 6.203$ \\
\hline 6 & 15.0 & 39.3 & 101 & -21 & 静豚內注射 \\
\hline
\end{tabular}

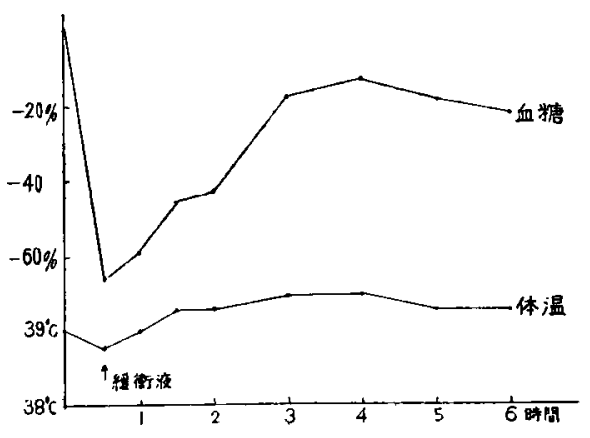




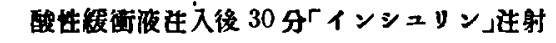

\begin{tabular}{|c|c|c|c|c|c|}
\hline 䄯，邀 & 室溫 & 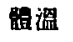 & 血糖国 & 㙕减率 & 考 \\
\hline 注 射前 & $\begin{array}{r}\mathrm{C} \\
8.0^{\circ}\end{array}$ & $\begin{array}{r}\mathrm{C} \\
38.5^{\circ}\end{array}$ & $\begin{array}{c}\mathrm{mg} \% \\
104\end{array}$ & $\%$ & \\
\hline 役工/2時間 & 10.0 & 39.0 & 102 & -2 & 體重 $2500 \mathrm{~g}$ \\
\hline 1 & 1.10 & 39.7 & 41 & -61 & 娞衝棭 $10 \mathrm{co}$ \\
\hline $1 \%$ & 13.0 & 39.9 & 47 & -55 & $\mathrm{P}_{\mathbf{H}} 6.330$ \\
\hline 2 & 14.0 & 39.7 & 61 & -41 & 静辰內注射 \\
\hline 3 & 15.0 & 39.3 & 93 & -11 & 「インシュ \\
\hline 4 & 15.0 & 39.1 & 84 & -19 & リン」栺重 \\
\hline 5 & 15.0 & 39.1 & 83 & -20 & 每 kg 1單位 \\
\hline 6 & 15.0 & 38.8 & 92 & -11 & 静眿内注射 \\
\hline
\end{tabular}

「インシニリン」ト同時二、或八交互二酸性缓皟

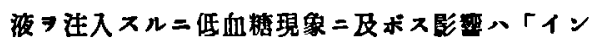

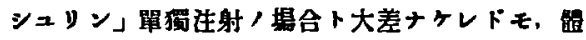

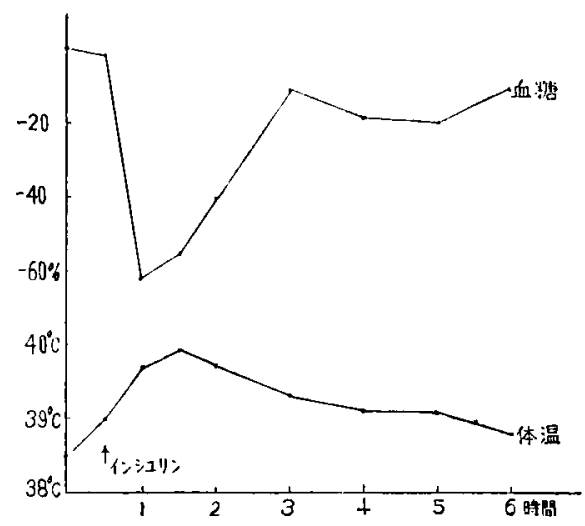

溫ハ相當上昇セり・然レドモ前項赛铪ヨリハ輕度 ニシテ持綠時間モ亦短縮サレタルラ見ル。

\section{第 5 章總括立证二考察}

「アトレナリン」ト「アルカリ性燐酸監粰衝 液ト)合併注射アナシタルニ「アドレナリン」

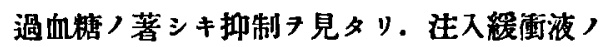
斯カル抑制現象二斩スル作用機辅二八種々ナ ル因子ノ存スルナランモ，第 1 報余，崖駸战 樍，余卜同條件ノモト二血中燐酸，消長 7 橎 察七ル故原田，業樍，又第 2 章詳述，諸家， 實驗結果等ョリ考フルニ，少クトモ其入因了

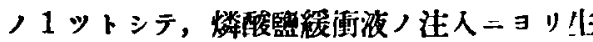
铻内梏 (Éndogener Zucker) 卜燐酸卜ノ所 謂Phosphorylierung 起り罱 $x=$ 榶, 遠元能 カフ失ヒタル二非ザルヤト思考サルルナリ。

「アドレナリン」ト同時ニ「アルカリ」性䌅 街淮ノ注射ナナシタル二體溫八相當上昇スル モ，「アルカリ性緩㣫液單獨注射二比三輕度 ニシテ且持続時間短シ． 余八第 1 報二於テ

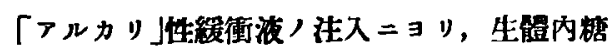

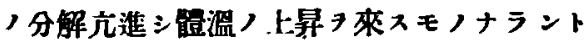

ノ結論二到達セシガ本宾驗ニテ體溫ノ上昇度

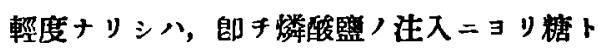
, Phosphorylierung 起り更二分解/過程 フ辿レルモ,「アドレナリン」第二次的作怕 (Acidosis etc) $=\Xi$ り然燒機轉/妨ゲラレタ ルモノト解サル。

次二「インシュリン」ト同時二「アルカリ」性

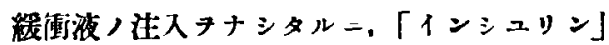
ニョル低血糖現象二八見ル可キ影犁モ及ボサ ザリシモ，髐溫！上昇八殊二著明二シテ，余 ノ何レノ賽驗二於タルョリモ通二高キ上昇度

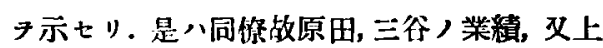
迅諸家ノ從來ハ「インシュリン」/作用機轉二 网スル成精等ヨリ考フルニ，燐酸「イォン」， 水酸化「イオン」/增加，欢「ンシュリン」固 有，作用ニヨリ糖，然焼最モ昰盛トナリタル モノト思惟サル。 


\section{第 6 严結論}

1）正常家鬼ニ「フドレナリン」ト同時二

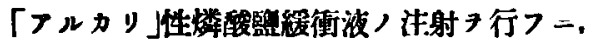

「フドレナリン」過血糖ノ萃シキ挪制ト，相當 度ノ體溫上昇习見ル。

2）「アドレナリン」ト同時二酸性頪衔液， 注入ヨナス二, 過血糖八增强サレ輕度ノ體溫 上昇來セッ。
3）「インシュリン」ト同時ニ「アルカリ性

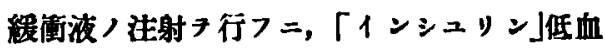
煻二八影繁ナキモ著明ナル體溫ノ上昇ヲ招來 セり.

4)「インシュリン」卜同時二酸性絠衝被

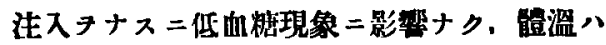
相賞上昇七り。

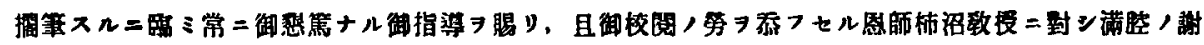
窟ワ捧グ.

\section{文}

1) Cori, J. of biol. chem. 63, p. 253, 1925.2 2) Moraczeruski ". Jintner, Bioch. Z. Bd. 125, 1921. 3) Geiger, Ebenda Bd. 223, S. 190, 1930, 4) Cori u. Croi, J. of biol. chem. 74, I. 321, 19:8; Bd. 84, p. 682, 1939. 5) Sahyun u. Lick, T. uf biol. ohem. 85, p. 1, 1929 . 6) Junke.sdorf". Toeroek, Arch. f. Physiol. Bd. 216, s. 549, 1927. 7) Geiger ". Schmidl, Aroh. f. exp. Patl. n. Phnrm. Bd. 134, S. 173, 1928. 8) 中冢茫灭, 日本架物學雜誌，第10卷，第3蹠，昭和年57月.9) Collnzo u. Puyal, Klin. W. Nr. 47, S. 1947, 1932. 10) Fröhlich u. Pollak, Arch. f. exp. Puth. u. Pharm. Bd. 77, S. 265, 1914. (11) Gottschalk ". Pohle, Arch. f. exp. Path. u. Pharm. Bd. 95, 8. 64, u. 75, 1922. 12) Underhill, J. of biol. chem. Bd. 25, S. 463, 1916. 13) Elias, Popescu-Motesti u. Rndoslav, Bioch. Z. Bd. 138, S. 294, $1923 . \quad$ 14) Fujimaki, Arch. f. exp. Path. u. Pharm. Bd. 102, S. $236-243,1924$. 15) Bricker, Kl. W. Nr. 52 ,

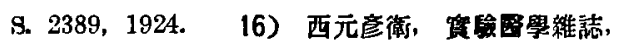
第 13 告，259-275頁, 昭和 4 年. 17) Collazo, Händel u. Rubino, Kl. W. Nr. 3, 8. 323, 1924. 18) Allan, Dieckson u. Markmuits, Amer. j. of physiol.
70, p. 333. 1924. 19) Endie, Macleod $u$. Noblel, Ebendit 72, p. 614, 1925.20$)$ Kinoknea, Toloku J. of exp. Med. 5, S. 438, 1924-25. 21) Ballinger ". Hartmam, J. of biol. chem. 64, p. 91,

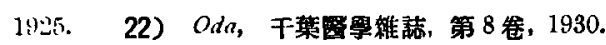
23) Moraczetuski z. Lindner, Dtsch. Aroh. f. kl. Med. Bd. 12l, 1917. 24) Faeta, Verhandl. d. Kongress f. inn. Med. 26, 1919，25）中村，京都

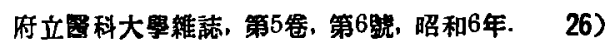

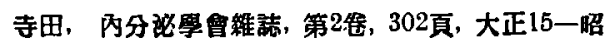
和2年. 27) Bentie ". Milrog, J. of physiol. 60 , p. 379, 1925.28$)$ Sacks, Amer. J. of physiol. 81, p. 276, 1927. 29) Fischler u. Schmidl, Arch. f. exp. Path. u. Pharm. Bd. 155, 8. 91-113, 1930. 30) Epstein, zit nach. Wibokuro u. Epstein. 31) Winokiuro u. Epstein, Arch. f. exp. Path. u. Pharm. Bd. 161, 1931. 32) Feinschmid u. Ferdmann, Bioch. Z. Bd. 205, S. 325, 1929 . 33) T. Tsuchtschenko, Ebendn Bd. 15, S. 365, 1908. 34) Gratinesci, Arch. f. exp. Puth. n. Plarm. Bd. 123, S. 197, 1913.35$)$ Ascher, Biooh. Z. Bd. 201, S. 148, 1924. 36) Gantenberg, Arch, f. exp. Path. 11. Pharm. Bd. 152, s. 187, 1927. 37) Burn "t. 
Daic, T. of physiol. 59, p. 164, 1924 . 38) Bissin er th. Lesier, Hiuch. Z. Bd. 168, S. 398, 1926. 39) Cori u. Cor $i$, J. of biol. chem. 70, p. 557,

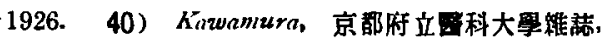
第2费, 16!頁, 1925 . 41) Newberg, Gotsschalk u. Strauss, Dteoh. Med. W. S. 1407, 1923, 42) Neuberg u. Gottschalk, Bioch. Z. Bd. 146, 8. 161, u. 185, 1924. 43) Dudley u. Marrian, Bioch. J. Bd. 17, p. 435, 1923. 44) Brutrsch, M. Kl. Nr. 3, 1923. 45) Bakin, Brit. J. exp. Pnth. 4, p. 310, 1923. 46) Gigon u. Slaub, Kl.W. S. 1670, 1923. 47) Macleod, zit nach Rubino, Vurelu u. Colluzo, Kl. W. S. 2186, 1928.48 ) vitessu u. Popescit-Inotesti, Ebendu. 49; Macleod, Brit. med. J. 1, p. 45, 1924. 50) Bissinger, KI. W. S. 2233, 1923, 51) Lesier, zit nnoh Rubino, Varelu u. Cullazo. 52) Bindi, Ebendu, 53) Rubino, Varela u. Collazo, Kl. W. S. 2186, 1928. 54) Staub, Ergeb. d. inn. Med. u. Kinderheilk. Bd. 31, s. 121, 1927. 55) Brigrs, Koechig, Doisy u. Weber, J, of kiol. Chem. 58, p. 721, 1923-24. 56) Harrop und Benedicl, Ebenda 59, p. 683. 1924. 57) Staub, Giunther u. Fröhlich, Kl. W. Nr. 2, 1923. 58) Wigglesworth, Woodrow, Smith u. Winter, J. of physiol. 57, S. 447, 1922-23. 59) Batherwick, Bell u. Hill, J. of biol. chem.
61, p. 241, 1924.60$)$ Katalama u. Killian, Ebenda 71, S. 707, 1924. 61) Virtanen u. Fornström, Foppe-Seyler's Z. Bd. 161, S. 218, 1926.

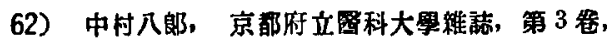

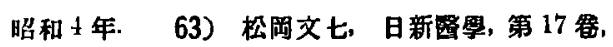
昭和2年. 64) Autova u. Wagner, Kl.W.Nr. 3, S. 231, 1924, 65) Brugsch ". Horster, Med. K1. Bd. 22, S. 81, 1926. 66) Virtanen, Bjoch. Z. Bd. 171, S. 76, 1926 . 67) Cori, Pbysiol. Rev. 11, S. 143, 1931. 68) Lawaczek, Bioch. Z. Bil. 145 , s. 351,1924, u. Kl. W. S. 1858,1925 . 69) Collazo u. Lewicki, Bioch. Z. Bd. 158, S. 136, 1925. 70）松井度事, 井上隆使, 長崎图學會 雜誌, 第8昭和5年. 71) Bang, Der Blutzucker Wiesbnden S. 35,1913 . 72) Hirayama, 'Tohoku J. of exp. Med. 7, s. 346, 1926. 73) 北村 那太郎，日本內科學會踓誌，第12第，第10號; 京都 府立置科大學雓志, 第 1 卷, 第3暏. 74) Wiecowski, Kl. W. N. 30, S. 1382, 1924. 75) 長谷川雅雄. 兒科雜誌，373跟，81頁，昭和6年，76）小室昌義. 日本内分泌學雉誌，第4巷，6路及ビ第5卷，第6跳，

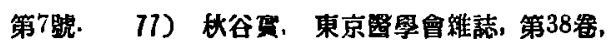
第l1號- 78) Magenta u. Biasotti， 1925；吉岐氏 日本消化器病學會雓誌, 27 卷, 昭和3年. 79) $J$ Abelin u. Goldner, Kl. W. Nr. 36, u. 37, 1925. 